\title{
DETECTION OF ANTHOCYANINS OF FLOWER EXTRACTS OF Desmodium gangeticum (L) DC
}

\author{
V.K. PRABHAT ${ }^{\mathrm{a}}$ AND NANDJEE KUMAR ${ }^{\mathrm{b} 1}$
}

Department of Botany, Magadh University, Bodhgaya, Bihar, India

\begin{abstract}
The present paper deals with the detection of anthocyanins of flower extract of Desmodium gangeticum (L) DC. Anthocyanins are glycosidic pigments usually found as essential constituents of flower petals or coloured leaves. They are antioxidant, antiviral and antimutagenicity and play important role in biological system. $2.00 \mathrm{~g}$ of flower petals of Desmodium gangeticum (L) DC were dissolved in $2 \mathrm{M} \mathrm{Hcl}$ in a test tube and heated $100^{0} \mathrm{C}$ for $5 \mathrm{mts}$. The solution wascooledand washed with ethyl acetate to remove the flavonoids followed by filtration. The filtrate was further heated with amyl alcohol at $80^{\circ} \mathrm{C}$ for $5 \mathrm{mts}$ followed by filtration. The filtrate contained anthocyanin so the filtrate was spotted on Whatman's filter no 1 and was placed in the chromatographic jar for separation of anthocyanins by using the solvents:

\section{Forestall conc $\quad-\quad$ HCl. $\mathrm{CH}_{3} \mathrm{COOH}_{2} \mathrm{H}_{2} \mathrm{O} \quad-\quad 3: 6: 1$}

2. Formic acid conc $\quad-\quad$ Hcl.HCOOH.H $\mathrm{H}_{2} \mathrm{O} \quad-\quad 2: 5: 3$

The coloured spots appeared on the chromatogram indicated anthocyanin. From the colour of the individual spot, anthocyanins were differentiated and detected.The $\mathrm{Rf}$ value of the marked spots was noted and different anthocyanins were confirmed by comparing the respective Rf value. The results confirmed three types of anthocyanin namely cynidin, peonidin and petunidin.
\end{abstract}

KEYWORDS: Desmodium gangeticum (L) DC., Forestall Conc. and Formic Acid Conc.

Fabaceae is one of the valuable families from agricultural and pharmaceutical point of view. The fabacious plant species are distributed throughout the world both in plains and hills. Desmodium gangeticum has been a rich source of medicines and proteins.

Anthocyanins are the essential constituents of biological system. They are soluble coloured pigments. In flower petals, there are anthocyanins associated with flavones and flavonoids which them attractive coloured. As the anthocyanins are antioxidant, antiviral and antimutagenic, so they are widely used by the health conscious people.

\section{MATERIALS AND METHODS}

Two grams of flower petals of Desmodiumgangeticum were heated at $100^{\circ} \mathrm{C}$ in $2 \mathrm{M} \mathrm{HCl}$ in a test tube for $15 \mathrm{mts}$, then cooled down and washed with ethyl acetate to remove the flavonoids followed by filtration. The filtrate was further heated with amyl alcohol at $80^{\circ} \mathrm{C}$ for $5 \mathrm{mts}$ followed by filtration. The filtrate contained anthocyanins (Davis and Mazza, 1997).

Now the anthocyanin solution (filtrate) was spotted on whatman's filter paper no 1 and was placed in a chromatic jar for 12 hours for separation of different anthocyanins by using the solvent forstallconc $\left(\mathrm{HCl} . \mathrm{CH}_{3} \mathrm{COOH} . \mathrm{H}_{2} \mathrm{O}: 3: 6: 1\right)$ and conc formic acid ( $\mathrm{Hcl} . \mathrm{HCOOH} . \mathrm{H}_{2} \mathrm{O}: 2: 5: 3$ ). The coloured spots appeared on the chromatogram were marked and their colour also was noted. The distance of marked spots travelled on the chromatogram was measured from the source and $\mathrm{Rf}$ value of each individual marked spot was calculated by dividing with maximum distance travelled by the solvent. On the basis of $\mathrm{Rf}$ value and colour of different spots the anthocyanins were detected and confirmed.

\section{RESULTS AND DISCUSSION}

The anthocyanins are highly stable compounds widely used in medicines (Baldi et al.,, 1995). Metivier et al.,, 1980 and Jackman et al., 1996 studied the solvent extraction of anthocyanins and their biochemical properties.

The present studies revealed that three spots were developed on the chromatogram each representing an anthocyanin. The deep magneta colour of the spot indicated cyanidin, magneta colour peonidin and purple colour petunidin. The Rf value of these spots confirmed the presence of cyaniding, peonidin and petunidin in the petal extract of Desmodium gangeticum (L) DC. 
PRABHAT AND KUMAR: DETECTION OF ANTHOCYANINS OF FLOWER EXTRACTS OF Desmodiumgangeticum (L) DC

Table 1: Chromatographic separation of anthocyanins in petal extract of Desmodium gangeticum(L)DC.

\begin{tabular}{|c|c|c|c|c|c|}
\hline $\begin{array}{c}\text { Sl. } \\
\text { No. }\end{array}$ & $\begin{array}{c}\text { Distance travelled } \\
\text { by the spot }(\mathrm{cms})\end{array}$ & $\begin{array}{c}\text { Distance travelled } \\
\text { by solvent }(\mathbf{c m s})\end{array}$ & Rf & colour of the spot & $\begin{array}{c}\text { Anthocyanin } \\
\text { detected }\end{array}$ \\
\hline 1. & $\mathbf{6 . 4 0}$ & $\mathbf{8 . 0 0}$ & $\mathbf{0 . 8 0}$ & Deep magneta & Cyanidin \\
\hline 2. & $\mathbf{2 . 9 0}$ & $\mathbf{8 . 0 0}$ & $\mathbf{0 . 3 6}$ & Magneta & Peonidin \\
\hline 3. & $\mathbf{1 . 6 0}$ & $\mathbf{8 . 0 0}$ & $\mathbf{0 . 2 0}$ & Purple & Ptunidin \\
\hline
\end{tabular}

\section{REFERENCES}

Baldi A., Romani A., Mulinasi N., Vincieri F.F. and Casetla B., 1995. HPLC/MS application to anthocyanin in Vitis venifera L. J. Agr. Food Chem., 43:21042109.

Baublis A., Spomer A. and Berber J.M.D., 1994. Anthocyanin pigments comparison of extract stability, J. Food sc., 59:1219-1221.

Cos T., de Bruyne N., Hermans S., Asoers D.V., Berghe A. and Vlietinck J., 2004. Proanthocyanidins in health care: current and new trends. Curr. Med. Chem., 11:1345-1359.

Davis A.J. and Mazza G., 1992. Separation and characterization of anthocyanins of Monarda fistulosaby HPCL, J. Agri. Food Chem., 40:13411345.

Jacklman R.L. and Smith J.L., 1996. Anthocyanins and betalains in Natural Food Colourants $2^{\text {nd }}$ Edition, pp. 244-309, Blachie \& Sons, London.

Metivier R.P., Francis F.J. and Clydesdale F.M., 1980. Solvent extraction of anthocyanins from wine pomace, J. Food Sc., 45: 1099-1100.

Niranjan A. and Tewari S.K., 2008. Phytochemical composition and antioxidant Potential of Desmodium gangeticum(L) DC. Natural Product Radiance. 7(1):30-35. 